Martin Marietta Energy Systems, Inc., Engineering Process Engineering

\title{
Further Characterization of the B-1023 Furnace for Use in Hypothetical Thermal Accident Testing of Shipping Containers in Accordance with 10 CFR Part 71
}

\author{
M. R. Feldman
}

Date Published-February 1992

MARTIN MARIETTA ENERGY SYSTEMS, INC.

Oak Ridge, Tennessee 37831

manging the

Oak Ridge National Laboratory Oak Ridge K-25 Site

for the

U. S. DEPARTMENT OF ENERGY under Contract No. DE-ACO5-84OR21400 


\section{CONTENTS}

Page

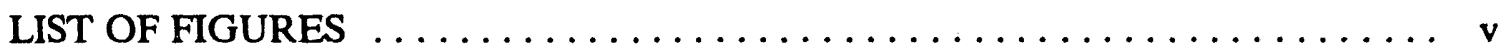

ACKNOWLEDGMENTS $\ldots \ldots \ldots \ldots \ldots \ldots \ldots \ldots \ldots \ldots \ldots \ldots \ldots \ldots \ldots \ldots$ vii

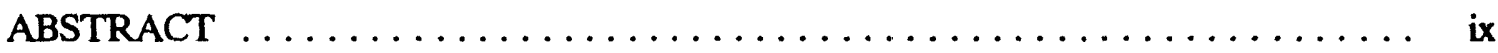

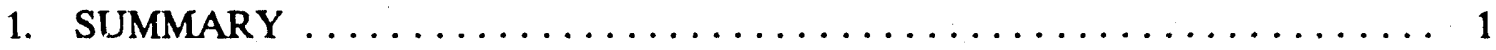

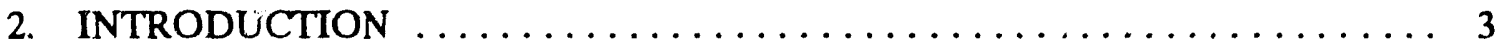

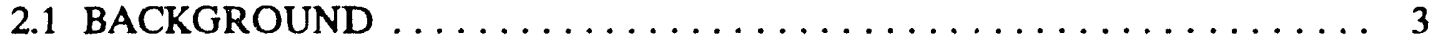

2.2 PROJECT OBJECTIVES $\ldots \ldots \ldots \ldots \ldots \ldots \ldots \ldots \ldots \ldots \ldots \ldots \ldots \ldots$

2.3 PROJECT DEVELOPMENT $\ldots \ldots \ldots \ldots \ldots \ldots \ldots \ldots \ldots \ldots \ldots \ldots \ldots$

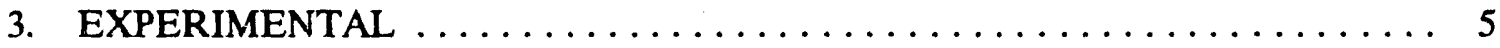

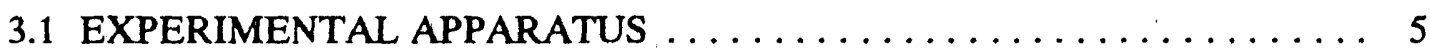

3.2 EXPERIMENTAL PROCEDURE $\ldots \ldots \ldots \ldots \ldots \ldots \ldots \ldots \ldots \ldots$

4. RESULTS AND DISCUSSION $\ldots \ldots \ldots \ldots \ldots \ldots \ldots \ldots \ldots \ldots \ldots \ldots \ldots$

5. CONCLUSIONS ............................ 19

6. RECOMMENDATIONS $\ldots \ldots \ldots \ldots \ldots \ldots \ldots \ldots \ldots \ldots \ldots \ldots \ldots \ldots$

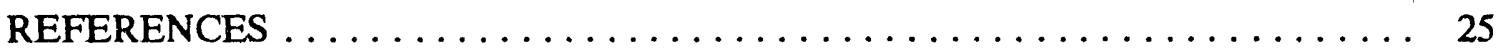

Appendix A. PRESENTATION OF EXPERIMENTAL DATA $\ldots \ldots \ldots \ldots \ldots 27$

Appendix B. DETERMINATION OF NONFUNCTIONING

THERMOCOUPLES $\ldots \ldots \ldots \ldots \ldots \ldots \ldots \ldots \ldots \ldots \ldots \ldots$ 


\section{LIST OF FIGURES}

Page

1. Steel plate in furnace $\ldots \ldots \ldots \ldots \ldots \ldots \ldots \ldots \ldots \ldots \ldots \ldots \ldots$

2. Approximate interior furnace thermocouple locations $\ldots \ldots \ldots \ldots \ldots \ldots$

3. DT-18 test stand top (upper) and side (lower) views $\ldots \ldots \ldots \ldots \ldots \ldots$

4. Temperature vs time for various furnace surface locations during experiment 1 , mock hypothetical thermal accident testing of DT-22 container with a furnace set point of $835^{\circ} \mathrm{C} \ldots \ldots \ldots 13$

5. Temperature vs time for various furnace surface locations during experiment 2, mock hypothetical thermal sicident testing of DT-22 container with a furnace set point of $885^{\circ} \mathrm{C} \ldots \ldots \ldots \ldots \ldots$

6. Temperature vs time for various furnace surface locations during experiment 3 , mock hypothetical thermal accident testing of DT-22 container in inactive furnace, with a preheat

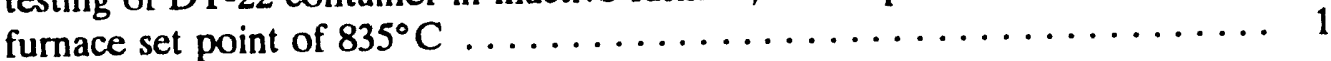

A.1. Temperature vs time for all monitored furnace locations during experiment 1 , mock hypothetical thermal accident testing of DT-22 container with a furnace set point of $835^{\circ} \mathrm{C}$

A.2. Temperature vs time for all monitored furnace locations during experiment 2 , mock hypothetical thermal accident testing of DT-22 container with a furnace set point of $885^{\circ} \mathrm{C}$

A.3. Temperature us time for all monitored furnace locations during experiment 3 , mock hypothetical thermal accident testing of DT-22 container in inactive furnace, with a preheat furnace set point of $835^{\circ} \mathrm{C}$ 


\section{ACKNOWLEDGMENTS}

The author acknowledges the help and influence of several individuals who aided in the preparation of this document. J. C. Anderson and W. R. Williams of Engineering Analysis were especially instrumental in providing original ideas, support, and comments as this work progressed. As always, G. H. Llewellyn, also of Engineering Analysis, acted as counsel throughout the project.

During the course of the experimental phase of this work, the workers in the metal preparation area at Building $9204-4$ at the Oak Ridge Y-12 Plant made the experiments a success. Without their diligent effort, the project would have failed. The members of the Energy Systems Independent Review Group committee and the Packaging Group of the Y-12 Plant Systems Safety Engineering Division and the Weapons Support Group of the Mechanical Design Division were most helpful throughout this project. E. Stumpfl of the Y-12 Packaging Program and S. D. Moses of the System Safety Engineering Division gave continuous input as well as support during this project. M. E. Boren and R. A. Vines of the ORNL Instrumentation and Controls Division assisted in the installation of furnace wall thermocouples.

This project was performed at the request of and was funded exclusively by the $Y-12$ Packaging Program. 


\begin{abstract}
The B-1023 furnace in Building 9204-4 at the Oak Ridge Y-12 Plant in Tennessee, is used for hypothetical thermal accident (HTA) testing of shipping containers in accordance with 10 CFR $71.73(\mathrm{c})(3)$. That document requires that a very specific radiant (and convective) thermal environment be present during an HTA test. Experiments have been performed to determine the surface temperatures that are present within the furnace which thus determine the radiant thermal environment. Conclusions have been drawn based on these experiments, and it has been found that it is possible to perform conforming HTA tests in this furnace if a very specific test routine is carefully followed. Recommendations concerning the procedure to be used during future tests have been made.
\end{abstract}




\section{SUMMARY}

During 1991 several series of experiments have been conducted to characterize the B-1023 furnace in Building 9204-4 at the Oak Ridge Y-12 Plant. Initial experiments performed in April were conducted for the purpose of establishing conditions which would ensure that all surfaces reached $800^{\circ} \mathrm{C}$ for the duration of hypothetical thermal accident (HTA) testing. The results of these experiments are reported in ORNL/ENG-10, Characterization of the B-1023 Furnace for Use in Hypothetical Thermal Accident Testing of Shipping Containers in Accordance with 10 CFR Part 71.1

Subsequent to these experiments, it became apparent that officials at DOE and Martin Marietta Energy Systems, Inc., had differing interpretations of 10 CFR 71.73(c)(3). The prevailing stance of DOE at that time meant that it might be necessary to operate the B-1023 furnace at temperatures elevated well above the $800^{\circ} \mathrm{C}$ temperature assumed to be needed when the initial work was undertaken. Thus it was deemed necessary to perform additional experiments in the B-1023 furnace for the sake of further characterization. The reasons for needing an increased temperature in the furnace are related to the emissivity of the furnace walls and the absorptivity of the package exterior; however, it is not the purpose of this report to address these issues. Rather, the purpose of this report is simply to quantify the surface temperatures present within the furnace under certain specified situations. It is hoped that these data can then be used in combination with DOE's interpretation of 10 CFR 71.73(c)(3) to arrive at the correct set-point temperature for the B-1023 furnace such that certifiable HTA testing can be carried out. 


\section{INTRODUCTION}

\subsection{BACKGROUND}

Over the past several years, DOE has reevaluated the certificatinn process for packages to be used to transport radioactive materials. These packages have always had to meet specifications set forth in 10 CFR 71,2 but recently two trends have developed: (1) the explicit wording of this document is being followed to a much greater extent, and (2) the interpretation of the wording of this document has come to be reevaluated. Thus, both physical tests and analytical methods used in documenting a package's ability to meet 10 CFR 71 are under much closer scrutiny.

Hypothetical accident thermal tests used for DOE certification are carried out in the B-1023 furnace in the Metal Preperation area of Building 9204-4 at the Oak Ridge Y-12 Plant. The quantity of power supplied to this furnace is a function of the reading of the control thermocouple which hangs down $-30 \mathrm{~cm}(1 \mathrm{ft})$ from the center of the ceiling of the furnace. Another thermocouple, located $\sim 30 \mathrm{~cm}(1 \mathrm{ft})$ behind this thermocouple and closer to the ceiling, acts as a safety mechanism such that if the control thermocouple malfunctions and the temperature within the furnace becomes significantly higher than the reading from the control thermocouple, power to the furnace is shut off. Unfortunately, these thermocouples measure ambient air temperatures within the furnace, and 10 CFR 71 calls for a specific radiant environment. This radiant environment requires that floor, wall, and ceiling surfaces maintain a specific temperature. In general, packages currently being tested in the B-1023 furnace consist of steel inner and outer containers with the area between the two filled with Celotex ${ }^{\mathrm{TM}}$. Celotex ${ }^{\mathrm{TM}}$ is a thermal insulating and shock-absorbing product made mostly from sugar cane plants. Thus it is possible that the placement of the control thermocouple (approximately directly above the package being tested) makes it possible for flames emanating from the package, due to the combustion of Celotex ${ }^{\mathrm{TM}}$, to influence readings obtained from this thermocouple. In turn, these could affect the power supplied to the furnace (up to and including the complete shutoff of furnace power). This action then could possibly affect interior furnace surface temperatures.

\subsection{PROJECT OBJECTIVE}

Simply stated, the objective of this project is to determine furnace surface temperatures present within the B-1023 furnace when various experiments, which approximate some possible test scenarios, are performed. The findings will then be used as a basis for guidance related to future HTA testing.

\section{PROJECT DEVELOPMENT}

Early project development is detailed in a previous report ${ }^{1}$ and will not be presented here. At the time the previous work was undertaken, it was believed that proof of furnace surface temperatures of $800^{\circ} \mathrm{C}$ would ensure compliance with the requirements of 10 CFR 71.73(c)(3). After experiments were completed, it was learned that other considerations might make it necessary for furnace surface temperatures to be considerably greater than $800^{\circ} \mathrm{C}$. These other considerations include both the emissivity of the furnace surfaces and the absorptivity of the packages being tested. These issues are not discussed 
here. This report is intended to determine the furnace surface temperatures that can be expected under various circumstances. Thus, when it has been determined that a specific minimum furnace surface temperature is needed for a specific HTA test, it will be possible to refer to this document to determine the control thermocouple set-point temperature to be used to maintain that minimum surface temperature for the duration of a HTA test.

In addition, during some previous HTA testing, the power to the furnace was cut off during testing because hot offgases emanating from the test package impinged upon the control thermocouple. Therefore this thermocouple was probably no longer a good indication of the average thermal environment within the furnace. Thus a package was tested in a mock HTA situation in which no power was supplied to the furnace during the entire test period to determine the effects of package offgasing on furnace surface temperatures. 


\section{EXPERIMENTAI.}

The experimental apparatus used and procedures followed during the experiments reported herein are very similar to those reported in a previous work. ${ }^{1}$ Therefore the depth of discussion of these topics will not be as complete as it was in the earlier work.

\subsection{EXPERIMENTAI, APPARATUS}

All experiments were performed within the B-1023 furnace in Building 9204-4 at the Y-12 Plant. A steel plate that measures approximately $8 \mathrm{ft} \times 5 \mathrm{ft} \times 1$ in. was placed on the furnace floor (see Fig. 1). This plate was instrumented with five thermocouples in a manner that allowed the plate surface temperature to be measured at each of these five positions.

For consistency, the system used to number the experimental thermocouples during the initial set of experiments is used here. Several of the thermocouples used earlier were not in operation at the time these experiments were performed. Thermocouples that were operating during these experiments were $1,2,16,17,18,19,20$, and the control thermocouple (see Fig. 2 or see foldout provided near the end of this document for thermocouple locations). Two thermocouples that had been mounted to the north wall of the furnace for previous experiments ${ }^{1}$ (thermocouples 1 and 2) were still in good operating order. Both of these thermocouples were monitored during the experiments described in this report. In the previous test, ${ }^{1}$ several thermocouples were mounted on each wall within the furnace. By the time the current experiments were performed, most of those thermocouples were no longer operating. But the experiments performed previously had shown that there were no significant differences in surface temperatures from wall to wall. The previous work also contained a single thermocouple mounted to the ceiling of the furnace that registered the ceiling surface temperature at that point. This thermocouple registered temperatures greater than or equal to those of the wall surfaces at all times. Because the most important temperature in this test was the minimum surface temperature, there was no reason to monitor the ceiling surface temperature. All thermocouples used in the experiments described herein were type $\mathrm{K}$ Chromel-Alumel ${ }^{3}$ encased in a stainless steel 316 sheath.

\subsection{EXPERIMENTAL PROCEDURE}

Three DT-22 containers were used in three separate experiments (one in each experiment performed). These DT- 22 containers were not damaged and were in usable condition. They consisted of an outer stainless steel container, Celotex ${ }^{\mathrm{TM}}$ insulation, and an inner stainless steel container. The inner containers were empty and bolted closed, but did not contain a seal. Each package was instrumented with a total of six thermocouples, three on the inner container and three on the outer container. Those thermocouples were placed on the packages to gather data for a separate study, so the resulting data are not discussed or presented here.

Each of the three experiments presented here was a mock HTA test, and each test was performed under different conditions. For each experiment, a package was placed inside the furnace on a test stand (Fig. 3) designed and used for DT-18 HTA testing. The diameter of the DT-22 packages used in these tests is slightly greater than that of the DT-18, thus fitting the DT-22 packages onto these stands was somewhat more difficult than fitting a 


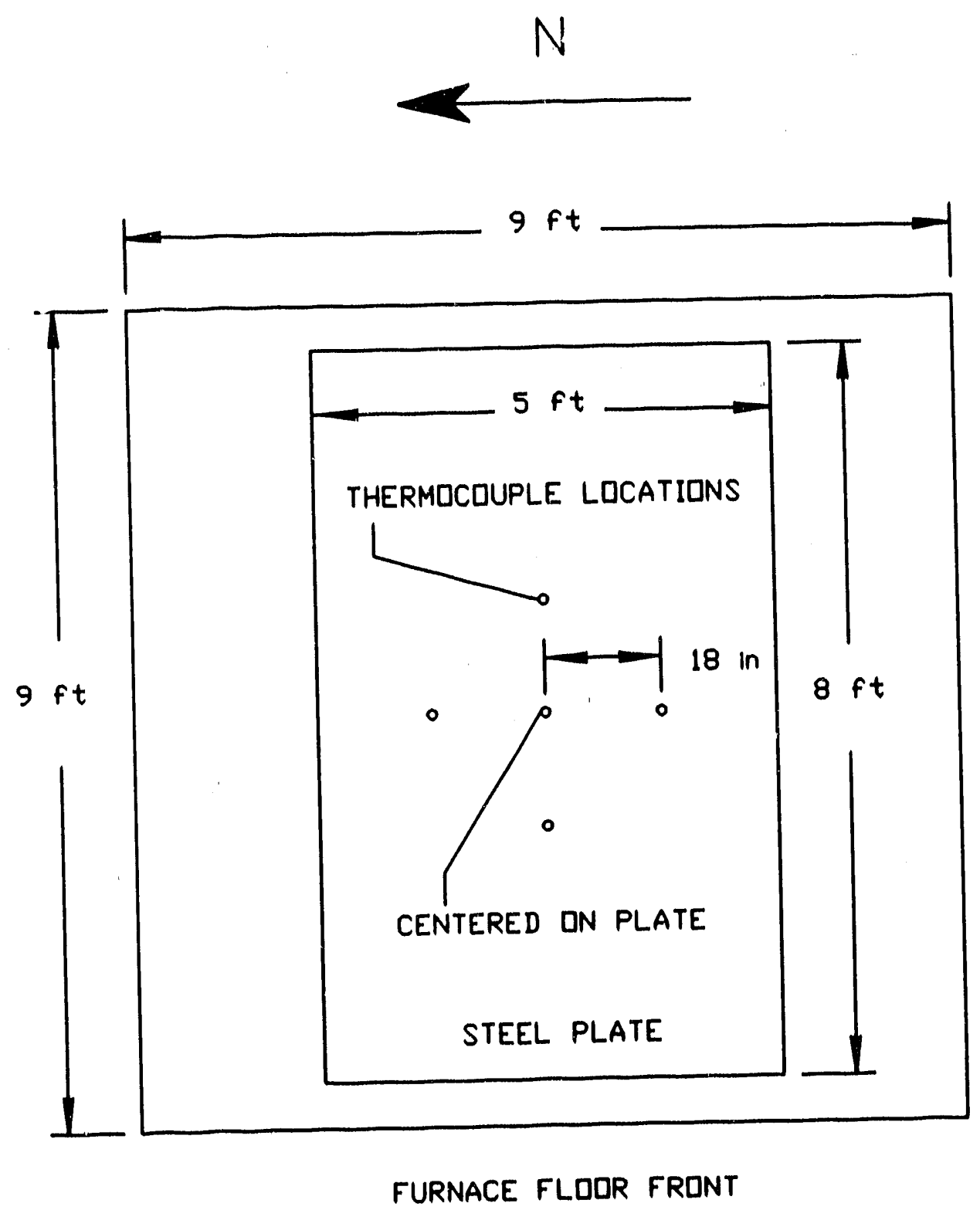

Note, All dimensions are approximate.

Fig. 1. Steel plate in furnace. 


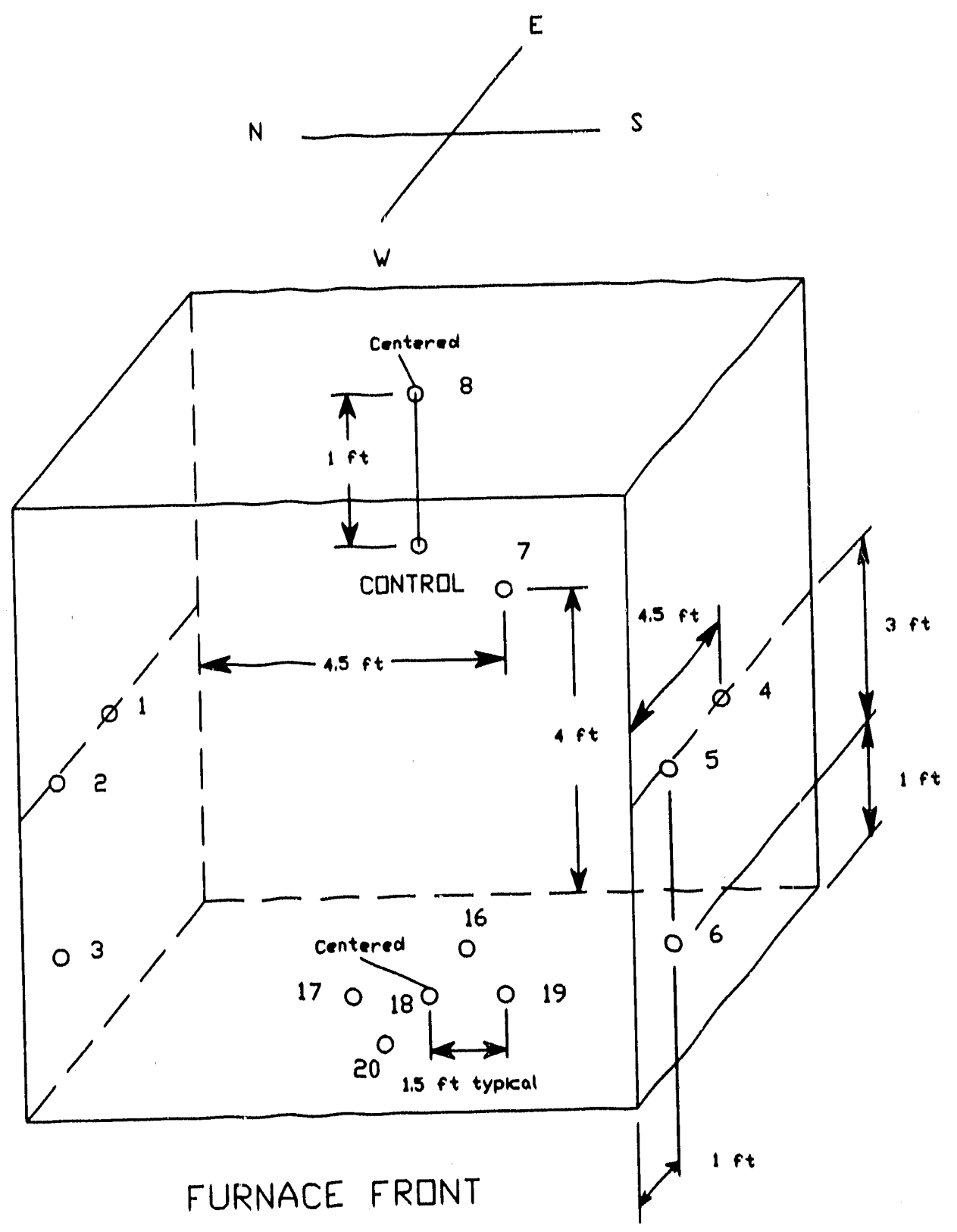

Note 1 All dimensions are approximate.

Fig. 2. Approximate interior furnace thermocouple locations. 

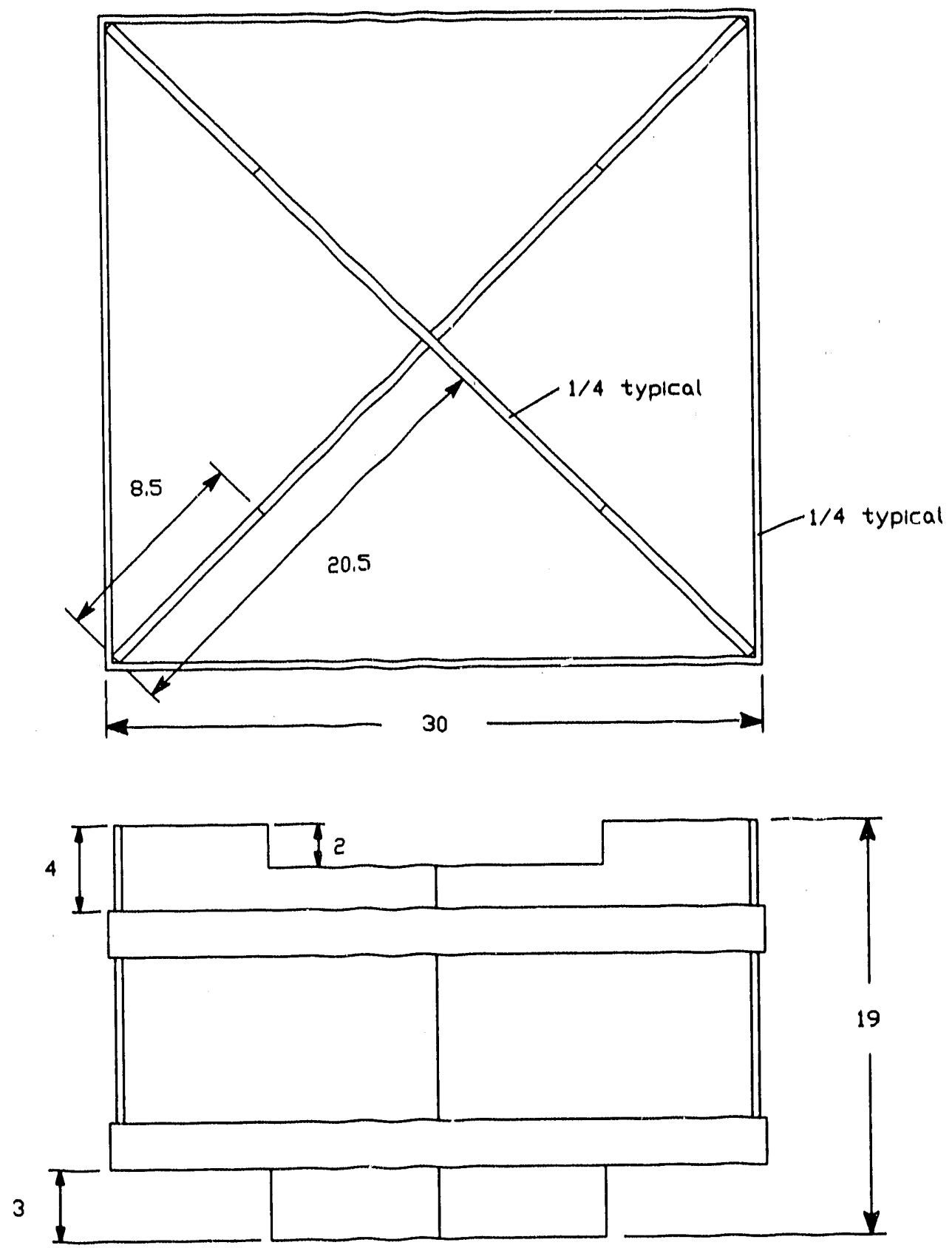

Note: All dimensions are in inches and are approximate.

Fig. 3. DT-18 test stand top (upper) and side (lower) views. 
DT-18 package. Nevertheless, with care the DT-22 packages were placed on these stands in an upright position. The ring that secures the outer container lid to the outer container body was in place for each of these experiments, but was not tightened. It was hoped that allowing the lid to be lrnse from the body would allow for a greater flow of offgases from the Celotex ${ }^{T M}$ within the outer container. Such a condition would, in general, be closer to actual HTA conditions in which a package would experience damage due to drop testing prior to thermal testing.

\section{Experiment 1. Mock HTA Testing of a DT-22 Package Using a Furnace Set Point of $835^{\circ} \mathrm{C}$}

The furnace had been sealed for $1 \mathrm{~h}$ and $53 \mathrm{~min}$, having last been opened to insert a test stand that had been preheated in a separate furnace. Normally, a minimum 2-h stabilization period would be called for in this situation, but in this case, the furnace set point had been lowered by $50^{\circ} \mathrm{C}$ (from $885^{\circ} \mathrm{C}$ ) at the beginning of the stabilization period, and it was found that interior furnace temperatures had not changed significantly in the 15-min period prior to the initiation of the test. The furnace door was opened approximately three-quarters of the way (just high enough to allow the package to be loaded), the packige was loaded. the furnace door was shut, and power was immediately restored to the furnace. From the instant the door began to open until the door was shut and power restored, $35 \mathrm{~s}$ elapsed. The package was left in the furnace for $33 \mathrm{~min}$ (from the time the furnace door began to lift), then was removed by lifting out the entire package/stand assembly.

Experiment 2 Mock H CA Testing of a DT-22 Package Using a Furnace Set Point of $85^{\circ} \mathrm{C}$

The furnace was heated from a cold start for $>24 \mathrm{~h}$ to a set-point temperature of $885^{\circ} \mathrm{C}$. During this heat-up period, the stand upon which the package was eventually placed was inside the furnace. The furnace door was opened approximately three-quarters of the way (just high enough to allow the package to be loaded), the package was loaded, the furnace door was shut, and power was immediately restored to the furnace. From the instant the door began to open until the door was shut and power restored, $50 \mathrm{~s}$ elapsed. The package was left in the furnace for $33 \mathrm{~min}$ (from the time the furnace door began to lift), then was removed by lifting out the entire package/stand assembly.

\section{Experiment 3. Mock HTA Testing of a DT-22 Package Using a Preexperiment Furnace Set Point of $835^{\circ} \mathrm{C}$ and No Power Delivery to the Furnace During the Experiment}

The furnace had teen sealed for $2 \mathrm{~h}$ and $2 \mathrm{~min}$, having last been opened to insert a test stand that had been preheated in a separate furnace. The furnace door was opened approximately three-quarters of the way (just high enough to allow the package to be loaded), the package was loaded, and the furnace door was closed. For this experiment, power to the furnace was not supplied after the package was loaded. From the instant the door began to open until the door was shut, $43 \mathrm{~s}$ elapsed. The package was left in the furnace for $33 \mathrm{~min}$ (from the time the furnace door began to lift), then was removed by lifting out the entire package/stand assambly. 


\section{PESULTS AND DISCUSSION}

Of the three experiments performed for this report, two (Nos. 2 and 3) were specifically designed to gather information that could be directly used to answer specific questions that have been raised concerning furnace testing under 10 CFR 71.73(c)(3). The other experiment (No. 1) was meant to be a baseline to which these other two experiments could be compared.

\section{Experiment 1. Mock HTA Testing of a DT-22 Package Using a Furnace Set Point of $835^{\circ} \mathrm{C}$}

Experiment 1, as stated above, was an attempt to establish a baseline to which the other experiments documented in this report could be compared. Figure 4 indicates the response of monitored thermocouples within the furnace during this experiment. The thermocouples in the floor plate showed large differences in temperatures, which is in contrast to previous experimental results. ${ }^{1}$ Two thermocouples, called 18 and 19 here, displayed unusually high readings (see Fig. A.1 in Appendix A). Each of these thermocouples registered temperatures we!l in excess of the furnace set-point temperature. After all of the experiments were completed, it was found that the leads to each of these thermocouples had been severed, possibly from having a test stand placed on top of them. Normally when leads are severed, the digital data logger used to record the temperatures displays a "RANGE" reading for each of these thermocouples. The process by which these unusually high temperatures were recorded is not fully understood, and for this reason these temperatures are not considered in this report.

The monitored wall temperatures, thermocouples 1 and 2 , dropped about 50 to $60^{\circ} \mathrm{C}$ in temperature during the first minute of the experiment and then rapidly recovered. Within the first $3 \mathrm{~min}$ after the initiation of the experiment, these wall temperatures were above $800^{\circ} \mathrm{C}$, and they remained there for the balance of the test. The control thermocouple displayed a fairly similar response, as it dropped $100^{\circ} \mathrm{C}$ in the first minute and then required less than 4 min to surpass the $800^{\circ} \mathrm{C}$ mark. The floor plate slowly lost temperature for about the first $6 \mathrm{~min}$ of the experiment, then gradually increased in temperature for the remainder of the experiment. Thermocouple 20 was $21^{\circ} \mathrm{C}$ below the set-point temperature prior to the initiation of the test. Thus, had this been an actual HTA test, and had it followed recommendations set forth in an earlier report ${ }^{1}$ with an intended set-point temperature of $835^{\circ} \mathrm{C}$, the true set-point temperature would have been increased until this thermocouple registered a minimum of $820^{\circ} \mathrm{C}$ (i.e., $15^{\circ} \mathrm{C}$ below the intended furnace set-point temperature. See recommendation 7, pg 22). During the test, this thermocouple dropped a total of $10^{\circ} \mathrm{C}$ to a minimum of $804^{\circ} \mathrm{C} 5 \mathrm{~min}$ into the experiment. This thermocouple then slowly rose to $810^{\circ} \mathrm{C}$ by the 18 -min mark and remained at this point for the balance of the test. The other two floor plate thermocouples had initial temperatures higher than thermocouple 20 . The changes in temperature which they measured were similar to thermocouple 20 otherwise.

Overall, the general response of thermocouples was similar to that which has been observed in the past. These general trends will now be used in comparisons to experiments with somewhat different operating parameters with the hope of establishing generalized test prosedures. 


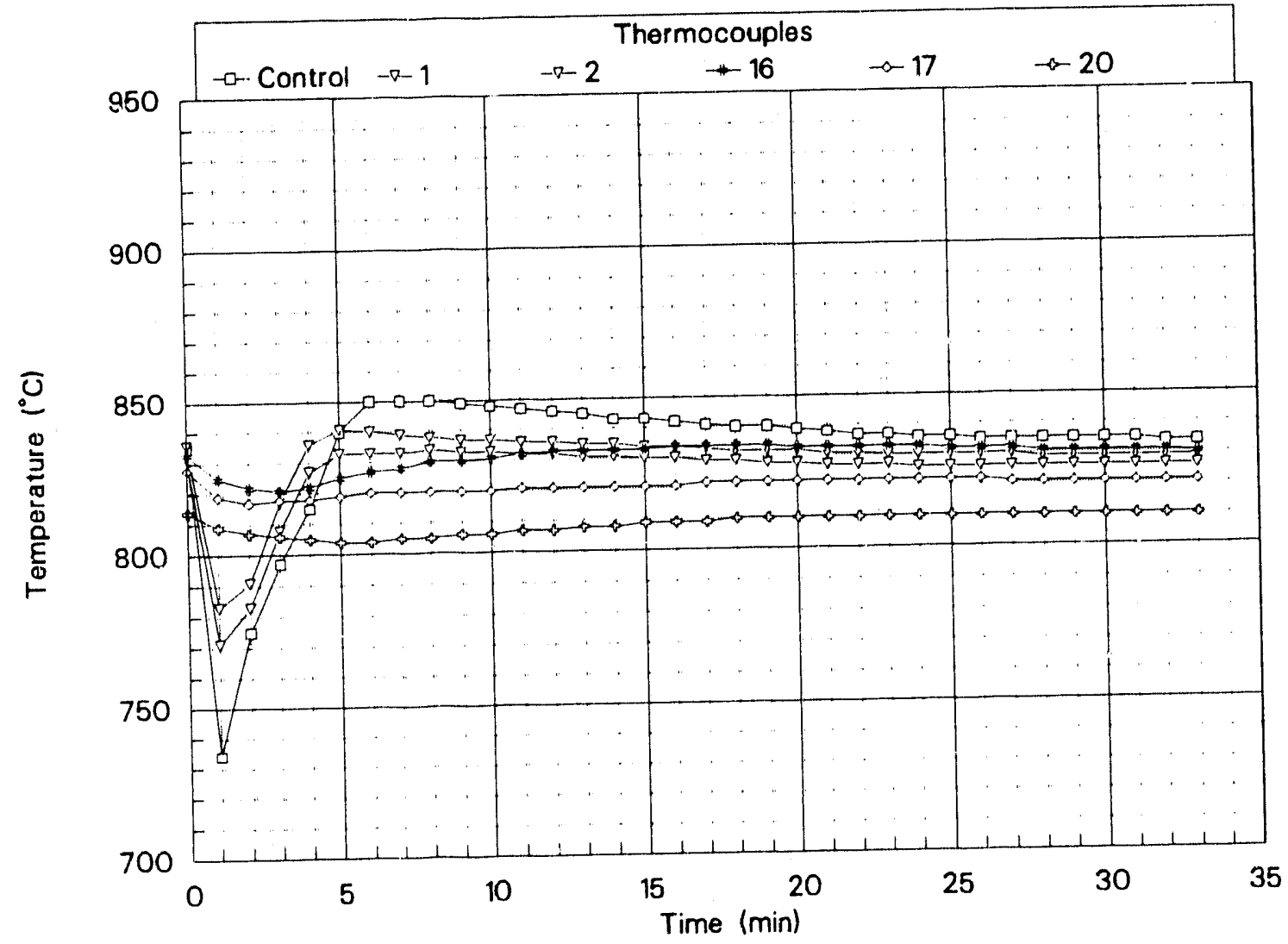

Fig. 4. Temperature vs time for various furnace surface locations during experiment 1 , mock hypothetical thermal accident testing of DT-22 container with a.furnace set point of $835^{\circ} \mathrm{C}$. 


\section{Experiment 2 Mock HTA Testing of a DT-22 Package Using a Furnace Set Point of $885^{\circ} \mathrm{C}$}

In a previous report, ${ }^{1}$ it was found that, during mock HTA testing of DT-18 packager, surface temperatures within the B-1023 iurnace wc uld be above $800^{\circ} \mathrm{C}$ within 6 min of the time the package was loaded if an $835^{\circ} \mathrm{C}$ set-point temperature was used and a carefully regimented test procedure was followed. Experiment 1 verified that this finding held true for DT-22 containers as well, although recovery was somewhat faster for experiment 1 ( $3 \mathrm{~min}$ ). When the previous tests were performed, it was believed that keeping surface temperatures at or above $800^{\circ} \mathrm{C}$ would ensure regulatory compiiance. More recently, the issue of exactly how surface temperature relates to compliance has become more complicated. At the time of this writing, there has not been a clear-cut directive from DOE on this issue, so it is necessary to characterize the furnace at a temperatuie well above the $800^{\circ} \mathrm{C}$ mark researched earlier. As stated above, the earlier research found that an offset $35^{\circ} \mathrm{C}$ between furnace set-point temperature and minimum allowable furnace surface temperatures was sufficient if careful test procedures were followed. This offset was found at $800^{\circ} \mathrm{C}$, and the point of experiment 2 was to find if this $35^{\circ} \mathrm{C}$ offset held true at a substantially higher furnace temperature. The "substantially higher" temperature chosen for this experiment was $850^{\circ} \mathrm{C}$. That is, an $885^{\circ} \mathrm{C}$ furnace set-point temperature was used in an effort to determine if the furnace surface temperatures would remain at or above $850^{\circ} \mathrm{C}$.

Some results from this experiment are displayed graphically in Fig. 5. It was found that, indeed, the $35^{\circ} \mathrm{C}$ offset is sufficient, but in this case just barely so. As was the case in experiment 1, two of the floor plate th. urmocouples were found to be defective at the end of the testing; thus their data are not presented here. The responses of all other thermocouples were similar to those of experiment 1 except that this experiment was performed at $50^{\circ} \mathrm{C}$ above the temperature of the previous experiment. The remaining three floor plate thermocouples which appeared to function correctly throughout the experiment, still showed a greater deviation from one another than had been recorded in previous experiments. ${ }^{1}$ Thermocouples 16 and 17 displayed behavior similar to that recorded for the floor plate in other tests. Their readings dropped for approximately $3 \mathrm{~min}$ to $-15^{\circ} \mathrm{C}$ below their initial readings. Each then began a slow climb upward, stabilizing at $\sim 10^{\circ} \mathrm{C}$ below their initial readings $15 \mathrm{~min}$ into the test. These thermocouples then remained within $2^{\circ} \mathrm{C}$ of this temperature for the balance of the test. Thermocouple 18 displayed similar behavior during the experiment as far as temperature change was concerned (i.e., slow fall for 6 min followed by a slow climb prior to stabilization $\sim 15 \mathrm{~min}$ into tile test), but this thermocouple began the experiment at $21^{\circ} \mathrm{C}$ below the furnace set-point temperature at $864^{\circ} \mathrm{C}$. If this test had been an actual HTA test in which the recommendations set forth in an earlier document ${ }^{1}$ and restated here had been in effect (see recommendation $7, \mathrm{pg} 22$ ), it would have been necessary to increase the furnace set-point temperature until all of the furnace surface thermocouples had reached within $15^{\circ} \mathrm{C}$ of the intended furnace set-point temperature. In this case, it would have been necessary to increase the furnace set point until a temperature of $870^{\circ} \mathrm{C}$ was reached at thermocouple 20 , as the intended set-point temperature was $885^{\circ} \mathrm{C}$. Nonetheless, the temperature at thermocouple 20 bottomed out at $850^{\circ} \mathrm{C}$ and then began to rise slowly. This behavior indicates that furnace floor surface temperatures vary almost linearly with the furnace set-point temperature. That is, at temperatures between 850 and $885^{\circ} \mathrm{C}$, the furnace surface temperatures respond in a manner similar to when the temperatures are between 800 and $835^{\circ} \mathrm{C}$. 


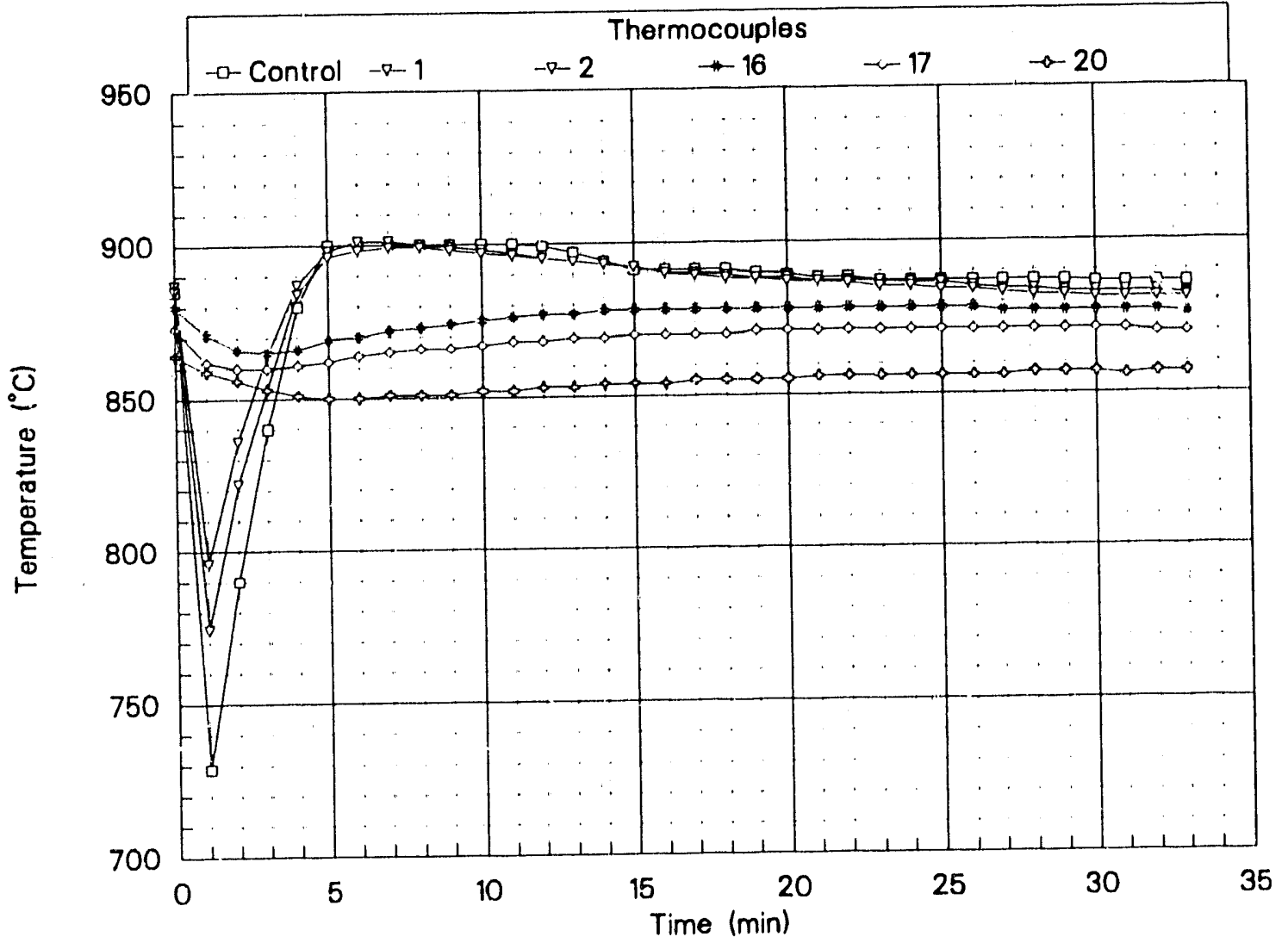

Fig. 5. Temperature vs time for various furnace surface locations during experiment 2 , mock hypothetical thermal accident testing of DT-22 container with a furnace set point of $885^{\circ} \mathrm{C}$. 
The two wall thermocouples which were monitored had dropped about $90^{\circ} \mathrm{C} 1 \mathrm{~min}$ into the experiment. Each of these thermocouples then quickly rebounded to above $800^{\circ} \mathrm{C}$ at the 2-min mark, and had climbed to above $850^{\circ} \mathrm{C}$ at the 3 -min mark. These thermocouples reached peak temperatures very close to $900^{\circ} \mathrm{C} 12 \mathrm{~min}$ into the test and then slowly fell to the mid $-880^{\circ} \mathrm{Cs}$ by the end of the experiment $(33 \mathrm{~min})$. Clearly this experiment shows that a $35^{\circ} \mathrm{C}$ offset between furnace set-point temperature and minimum surface temperature is a valid rule to follow. By following the recommendation that all measured interior thermocouple temperatures be within $15^{\circ} \mathrm{C}$ of the intended furnace set point, an added factor of safety will be gained to ensure that, after the initial cooldown and reheat due to package loading, all furnace surface temperatures remain above the required minimum wall temperature for the duration of the test.

Experiment 3. Mock HTA Testing of a DT-22 Package Using a Preexperiment Furnace Set Point of $835^{\circ} \mathrm{C}$ and No Power Delivery to the Furnace During the Experiment

Power to the B-1023 furnace is supplied through a proportional controller that acts upon information provided by the control thermocouple. This thermocouple hangs down $-30 \mathrm{~cm}(1 \mathrm{ft})$ from the center of the ceiling. The temperature measured by this thermocouple is not that of any of the radiating surf res within the furnace. Furthermore, the temperature that this thermocouple registers can be significantly affected by offgasing from a shipping container during an HTA test. When these offgases are hotter than the furnace set-point temperature, the result of offgas impingement upon the control thermocouple can be the reduction or complete stoppage of power to the furnace. When stoppage occurs, it might be possible for furnace surface temperatures (walls and floor) to fall significantly while control thermocouple readings remain high. Experiment 3 was undertaken in an attempt to help determine the effect of loss of power to the furnace during an HTA test. This test was performed in the same manner as experiment 1 except that power to the furnace was not restored after the container was placed in the furnace.

Figure 6 indicates the response of several furnace surface thermocouples along with the control thermocouple. For the five thermocouples shown here, temperature response for the first $2 \mathrm{~min}$ is similar to that of experiment 1 (Fig. 4). As indicated in Fig. 6, thermocouples that measure floor temperature $(16,17,20)$ display a slow loss of temperature by dropping about $10^{\circ} \mathrm{C}$ in the first $5 \mathrm{~min}$. These temperatures then stabilize somewhat until about the 20-min mark, after which a slow fall is seen until the end of the test. Wall thermocouples $(1,3)$ drop approximately 60 to $90^{\circ} \mathrm{C}$ in the first minute (as seen in experiment 1) and then recover, but not as rapidly as when power is restored. After about $8 \mathrm{~min}$, both of the wall thermocouples return to above $800^{\circ} \mathrm{C}$. The control thermocouple drops about $120^{\circ} \mathrm{C}$ in the first minute and then recovers in a manner similar to that of the wall thermocouples. The control thermocouple does not go above $810^{\circ} \mathrm{C}$ at any time during the test.

Data from this experiment render several interesting results. The offgasing from this DT-22 package was not as effective at heating the control thermocouple as has been observed in the past. During actual HTA testing, the control thermocouple is sometimes heated by the offgases to the point at which the proportional controller cuts off power to the furnace. This reaction is seen only when the control thermocouple is heated significantly beyond the 


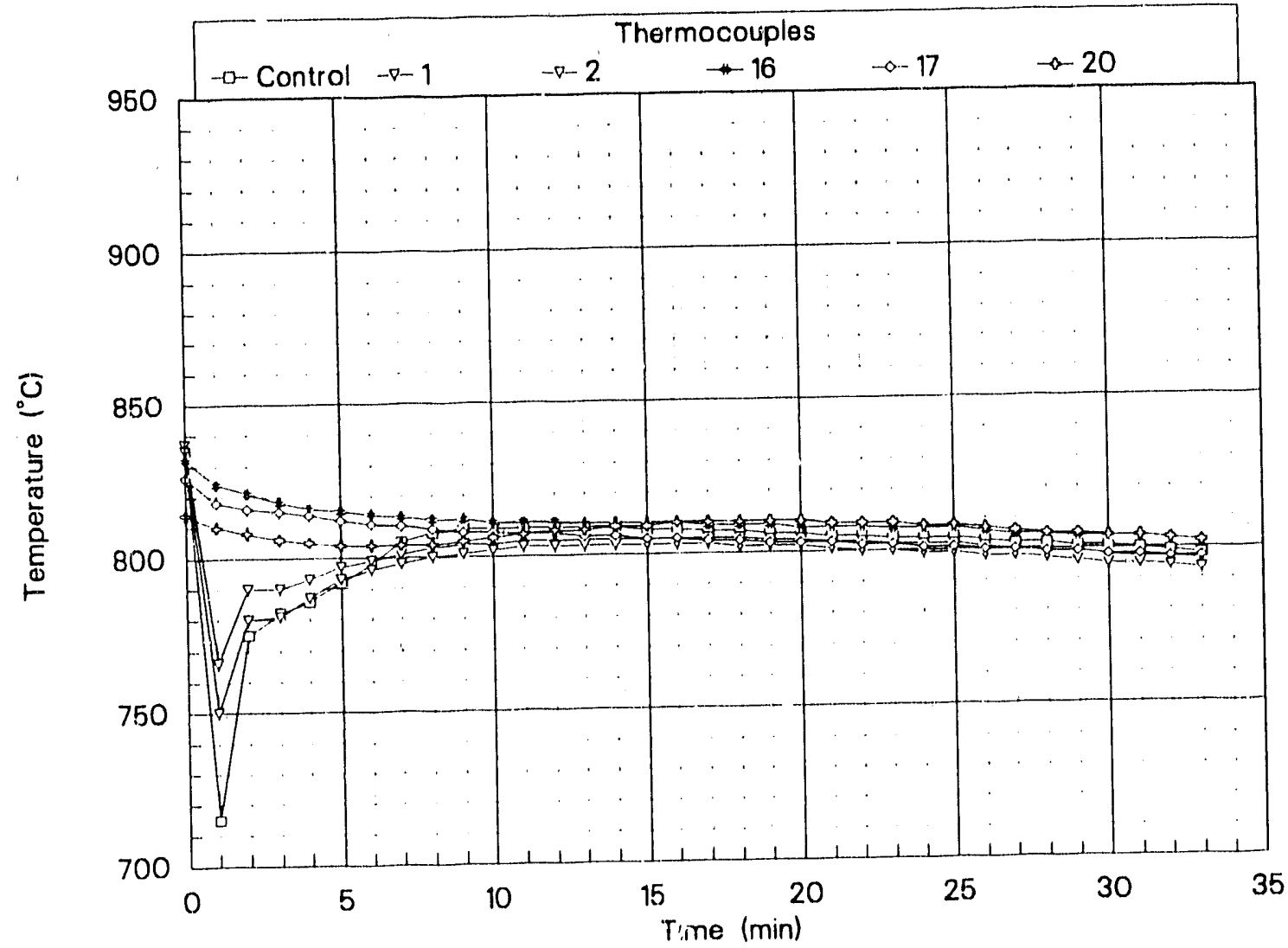

Fig. 6. Temperature vs time for various furnace surface locations during experiment 3 , mock hypothetical thermal accident testing of DT-22 container in inactive furnace, with a preheat furnace set point of $835^{\circ} \mathrm{C}$. 
furnace set point. That temperature did not occur in this instance, as the control thermocouple reached a maximum of $810^{\circ} \mathrm{C}$ and the furnace set point would have been $835^{\circ} \mathrm{C}$. Yet, for the first $20 \mathrm{~min}$, all thermocouples (after the initial $8 \mathrm{~min}$ ) registered at or above $800^{\circ} \mathrm{C}$. It is also interesting to note that no thermocouple readings dropped below $790^{\circ} \mathrm{C}$ during the last $20 \mathrm{~min}$ of the test. Probably the most significant finding in this experiment is the manner in which all measured thermocouple temperatures are within $8^{\circ} \mathrm{C}$ of one another from the 10-min mark until the end of the test. This behavior is not seen in other experiments, and leads to some interesting conclusions.

In previous experiments of this nature in which the furnace was empty (Ref. 1, experiments 2 and 6), it was found that during the first $10 \mathrm{~min}$ after power was cut to the furnace, the walls cooled more quickly than did the floor. After this initial period, all surfaces cooled at about the same rate, but the floor was distinctly warmer (about $10-15^{\circ} \mathrm{C}$ ) than any of the other furnace surfaces. Thus the results of this experiment suggest that the presence of the package in some way acts to homogenize the temperatuies within the furnace. This process could be due partially to radiative heat transfer but must likely is attributable to convective heat transfer. When experiments were perforned using an empty furnace, the only driving force for convection was temperature gradient. A gradient did occur, but it was only about $10^{\circ} \mathrm{C}$. When the package was in the furnace, there was violent offgasing and combustion taking place. The natural buoyancy of the offgases makes them rise initially, but apparently when they hit the ceiling they continue to travel down the walls of the furnace. This action can be termed a sort of "forced convection" and would account for the fact that furnace surface temperatures (including the floor) are very homogenous during the entire length of this experiment. The package used in this experiment did not overheat the control thermocouple in the same manner as during previous actual HTA tests. When overheating occurs, the distribution of temperatures within the furnace might not be as uniform as in this experiment, but it is apparent that when hot offgases are present, they tend to heat the entire furnace rather than just the control thermocouple and the ceiling. Nonetheless, the evidence of a single experiment is not sufficient to draw absolute conclusions. Recommendations presented below will not be affected significantly by this experiment. 


\section{CONCLUSIONS}

The experiments presented above coupled with those in a previous report ${ }^{1}$ indicate that it is possible to perform hypothetical thermal ace tests in the B-1023 furnace that meet the regulations specified in 10 CFR 71.73(c)(3). J perform these tests, great care must be taken in the manner in which the test is prepared, performed, and documented. Recommendations in Sect. 6 outline the steps for these tests. If these recommendations are followed closely, the results will be smooth, documentable, and regulatively certifiable tests.

Experiments carried out to this point suggest that there are two distinctly different thermal responses within the furnace. It is necessary for test procedures to be followed explicitly so that each response can be accounted for. Thermocouples mounted on the wall and the control thermocouple react in nearly the same manner, while thermocouples that measure the temperature of the floor plate respond quite differently. The walls lose temperature rapidly when the furnace door is opened for the package to be loaded, and then recover very quickly. The floor plate, on the other hand, responds much more slowly, as it loses only a few degrees when the furnace door is opened, but this temperature loss is spread over a longer period of time, and it does not recover its temperature well during the course of the test. There are two reasons for these different responses. The floor plate has a greater thermal mass than do the walls. That is why the walls respond more quickly than does the floor. This difference is compounded by the ? $\mathrm{st}$ that the walls are strung with heating coils while the floor is not. The heating coils $t$ ad to help the walls recover while they are not as efficient at helping the floor recover. A test strategy must be adopted that allows for these two different responses. The subsequent recommendations present a way to perform these tests that will accommodate both responses.

Unavoidably wall surface temperatures will fall below regulatory requirements when the package is loaded, but these surfaces will recover their temperatures rapidly, usually within 3 to $5 \mathrm{~min}$. It will not be possible to begin the clock on tests until the walls have reached the regulation temperature, but waiting for this to occur should not constitute too great an overtest to the package. On the other hand, if floor plate temperatures fall below the minimum required surface temperature, the slow response of this surface could dictate a long wait for reheat. The floor plate temperature should be sufficiently high prior to the loading of the package such that at no time does this surface temperature fall below the minimum required surface temperature. Because temperature drops of between 10 and $14^{\circ} \mathrm{C}$ have been seen on the floor plate, it is recommended that the minimum floor plate temperature prior to initiation of the package loading be $20^{\circ} \mathrm{C}$ above the minimum required surface temperatures for packages that can be loaded in $1.5 \mathrm{~min}$ (and $35^{\circ} \mathrm{C}$ above the minimum required surface temperature for packages that take between 1.5 and $3 \mathrm{~min}$ to load). It is important that these guidelines be followed precisely. Packages could be subjected to severe overtesting if it is necessary to wait for the floor plate to reheat to the minimum required surface temperature because the recommended procedures were not precisely followed. 


\section{RECOMMENDATIONS}

1. Testing should be closely coordinated with Metal Preparation persornel. Tests should be run only when the furnace can be dedicated to this jot for a minimum of $2 \mathrm{~d}$ (starting with a cold furnace); however, $3 \mathrm{~d}$ is preferred. The furnace floor and the mild steel plate should be cleaned of scale and debris that may have accumulated.

2. The morning of the first day should be a time to practice the procedures to be used during the test. Any stand to be used during the first test should be placed in the furnace prior to the 24-h heat-soak. Any thermocouples internal to the furnace to be used during the test should be attached to a data recorder at this time. When the furnace is first turned on, the readings from these thermocoup!es should be observed to ensure that they are functioning properly.

3. Five thermocouples should be placed in the mild steel plate on the furnace tloor. One thermocouple should be placed in the center of the plate; the other four thermocouples should be placed one each $45 \mathrm{~cm}(1.5 \mathrm{ft})$ to the left, right, rear, and forward of the center thermocouple. The thermocouples should be attached to holes in the plate, which are $3.2 \mathrm{~mm}(1 / 8 \mathrm{in}$.) in diameter and a maximum of $6.4 \mathrm{~mm}$ (1/4 in.) deep. The holes should be filled with a liquid-metal setting compound. Each thermocouple should then be pressed into a hole, and the liquid-metal compound should be allowed to set.

Furnace wall thermocouples should be used to determine furnace wall temperatures. At least two thermocouples should be located near the midpoint of the rear wall and should be monitored in the same manner as thermocouples on the floor plate (every minute for the duration of the test). At least two thermocouples should aiso be mounted on either the north or the south side wall near the midpoint. It is recommended that three thermocouples be placed on either the north or the south wall and three additional thermocouples be placed on the back wall. Each of these thermocouples will be monitored in the manner discussed in recommendations 6 and 8 .

Thermocouples that are herein referred to as "furnace surface thermocouples" include those that are mounted on the floor plate within the furnace as well as those that are mounted on the furnace walls.

4. Thermocouples placed on the test stand are not considered furnace surface thermocouples and therefore are not included in the requirements that are stated here for furnace surface and control thermocouples. Nonetheless, the use of thermocouples on the test stand is a good idea. Therefore, the stands upon which the packages are placed for testing should be thermocoupled such that their temperatures can be recorded. To monitor the temperatures of these test stands, a minimum of two thermocouples should be mounted on each stand. Thermocouples mounted on test stands should be mounted in the same manner as those mounted on the floor plate. It is recommended that three or four thermocouples be placed on each stand, that they be monitored in the same fashion as those on the floor plate, and that the same criteria for functionality be used. 
5. To determine the temperature at which the furnace controller should be set, it will be necessary to know the temperature that current DOE guidance requires for a certifiable lest. This temperature is referred to throughout these recommendations as the "minimum allowable furnace surface temperature." If practice loading determines that the package can be loaded in $1.5 \mathrm{~min}$ or less, the furnace heat-soak set-point temperature should be $35^{\circ} \mathrm{C}$ above the minimum allowable furnace surface temperature, and if the package requires between 1.5 and $3 \mathrm{~min}$ to be loaded, the heat-soak set-point temperature should be $50^{\circ} \mathrm{C}$ above the minimum allowable furnace surface temperature. The set-point temperature determined here is defined as the "intended furnace set-point temperature" and will be referred to as such throughout these recommendations. If the package requires longer than 3 min to load, additional testing will be necessary to determine the heat-soak temperature. In any case, the furnace should be set to $35^{\circ} \mathrm{C}$ above the minimum allowable furnace surface temperature after the package has been loaded into the furnace. The only time, after the package has been loaded into the furnace, that the set point should be higher than $35^{\circ} \mathrm{C}$ above the minimum allowable furnace surface temperature is when the control thermocouple is artificially heated by offgases; and it appears that monitored furnace surface temperatures may not reach or may fall below the minimum allowable furnace surface temperature. In this case, the furnace operator should adjust the furnace controls until the furnace power turns on and the desired temperatures are reached. This procedure will have to be done strictly by operator judgment with the concurrence of the test manager. Any adjustments made during testing should be entered into the official test log.

6. After practice has been fully completed and the operators and the test manager are comfortable with the manner in which the test will be performed, the furnace should be seaied and turned on by setting the furnace controller to the intended furnace set point temperature as determined in recommendation 5 . Data recordings should be initiated at this time, and these data should be retained as a part of the official test record. Recording the temperature each hour at this point will be satisfactory. The furnace should be allowed to heat for a full $24 \mathrm{~h}$.

7. Before a package is loaded into the furnace, all functioning (see appendix $B$ for determination of nonfunctioning thermocouples) monitored furnace surface thermocouples should register within $15^{\circ} \mathrm{C}$ of the intended furnace set-point temperature. If, after the heat-soak requirements have been met (i.e., $24 \mathrm{~h}$ for initial test and $2 \mathrm{~h}$ for subsequent tests), all functioning furnace surface thermocouples are not within $15^{\circ} \mathrm{C}$ of the intended furnace set-point temperature, it will be necessary to increase the furnace set-point temperature. The furnace setpoint temperature should be increased until all functioning furnace surface thermocouples register within $15^{\circ} \mathrm{C}$ of the intended furnace set-point temperature.

When all functioning furnace surface thermocouples have attained readings that are within $15^{\circ} \mathrm{C}$ of the intended furnace set-point temperature and all heat-soak requirements have been met, the package can be loaded into the furnace.

8. During tests, data should be recorded at least every minute. Data concerning the power being supplied to the furnace should be included if they are deemed necessary. 
9. For a test to be considered complete, the following criteria should be met: (1) the package should be left in the furnace for a minimum of $35 \mathrm{~min}$, and (2) all of the functioning (see appendix B for determination of functioning thermocouples) furnace surface thermocouples and the furnace control thermocouple should have registered at or above the minimum required furnace surface temperature for a consecutive 30-min period during the time the package is in the furnace.

10. For consecutive tests, at least $2 \mathrm{~h}$ should be required between tests to allow the furnace and test stand to thermally equilibrate. Stands to be used for tests other than the first of the day should be heat-soaked in another furnace. The 2-h period will begin after the stand for the next test has been placed in the B-1023 furnace, the B-1023 furnace has been sealed, and the B-1023 furnace power has been restored. All functioning monitored furnace surface thermocouples should register within $15^{\circ} \mathrm{C}$ of the intended furnace set-point temperature before the package is loaded (see recommendation 5). With a 2-h wait between tests, it may not be possible to complete more than three tests during a single shift of operator time. Thus, il may be necessary either to practice with members from two different shifts or have operators from a single shift work overtime when more than three packages are to be burned (or testing could resume the following day). It is recommended that operators be requested to work overtime, thereby ensuring consistency in the manner in which the job is performed without prolonging the process.

11. Data that should become part of the official test record include furnace temperature readings that show the length of the heat-soak prior to each test, all temperature readings taken during each test, data concerning the amount of power to the furnace during each test, and the length of time each test lasted. The temperature readings should include those of the control thermocouple, those of the steel plate at the bottom of the furnace, and those of the monitored furnace wall thermocouples. If available, temperature readings from the test stand should be included in the official test record. 


\section{REFERENCES}

1. M. R. Feldman, Characterization of the B-1023 Furnace for Use in Hypothetical Thermal Accident Testing of Shipping Containers in Accordance with 10 CFR Part 71, Oak Ridge, TN, 1992.

2. Code of Federal Regulations, Title 10, Part 71, January 1, 1988.

3. Manual on the Use of Thermocouples, American Society for Testing and Materials, Philadelphia, PA., 1970. 
Appendix A

PRESENTATION OF EXPERIMENTAL DATA 


\section{Appendix A}

\section{PRESENTATION OF EXPERIMENTAL DATA}

All furnace temperature data taken during the course of the experimental work discussed in this paper are presented below in graphical format. The data are organized by individual experiments. For each experiment, there is a single graph that includes the data presented in the main body of the text as well as data from two thermocouples (18 and 19) whose readings at times during the experiments did not appear to be characteristic of surface temperatures within the furnace. At the conclusion of the experiments, it was found that the sheath leading to each of these thermocouple junctions had become severed. Thus the readings from these two thermocouples are not considered in the text of the report. 


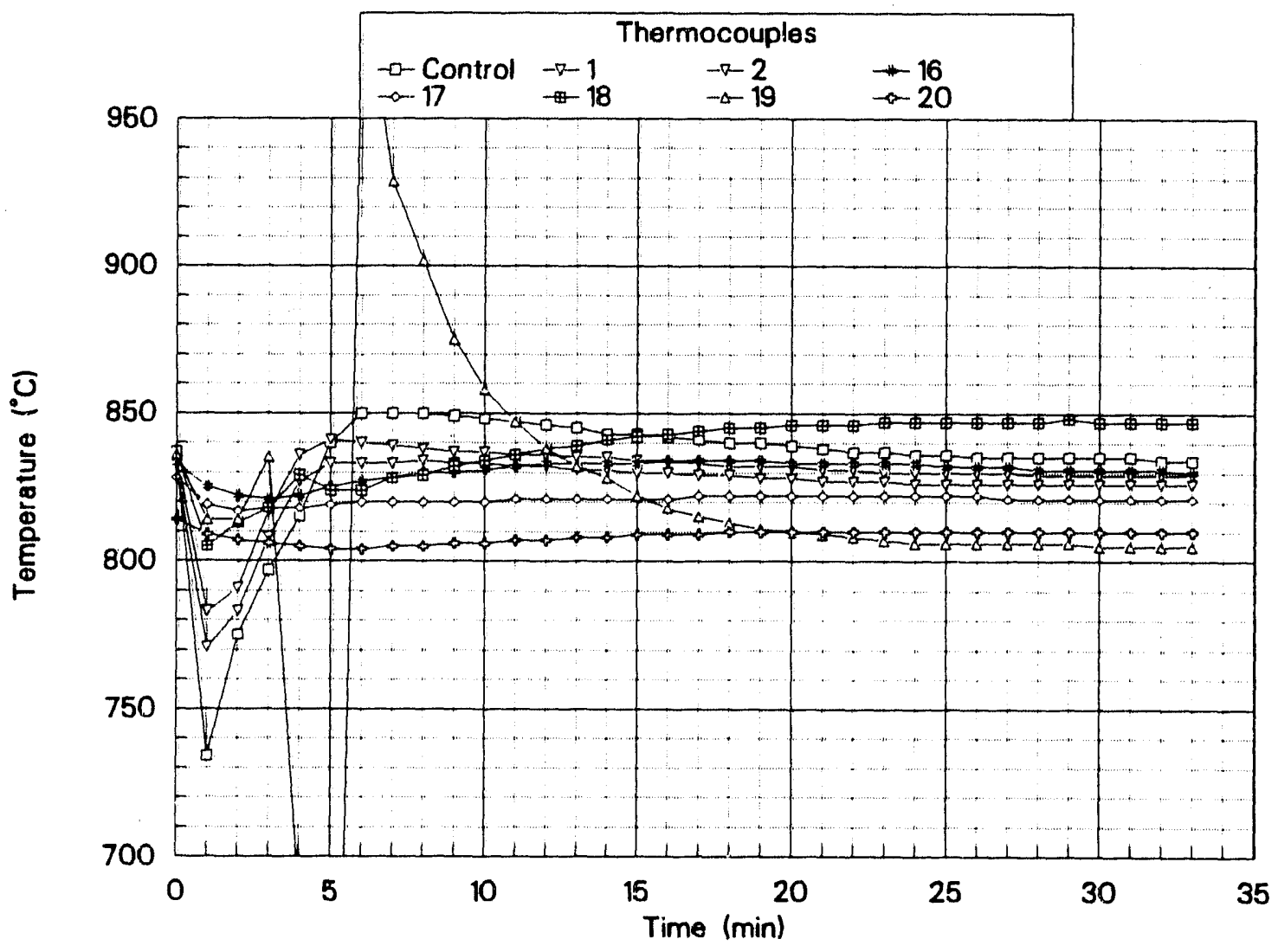

Fig. A.1. Temperature vs time for all monitored furnace locations during experiment 1, mock hypothetical thermal accident testing of DT-22 container with a furnace set point of $835^{\circ} \mathrm{C}$. 


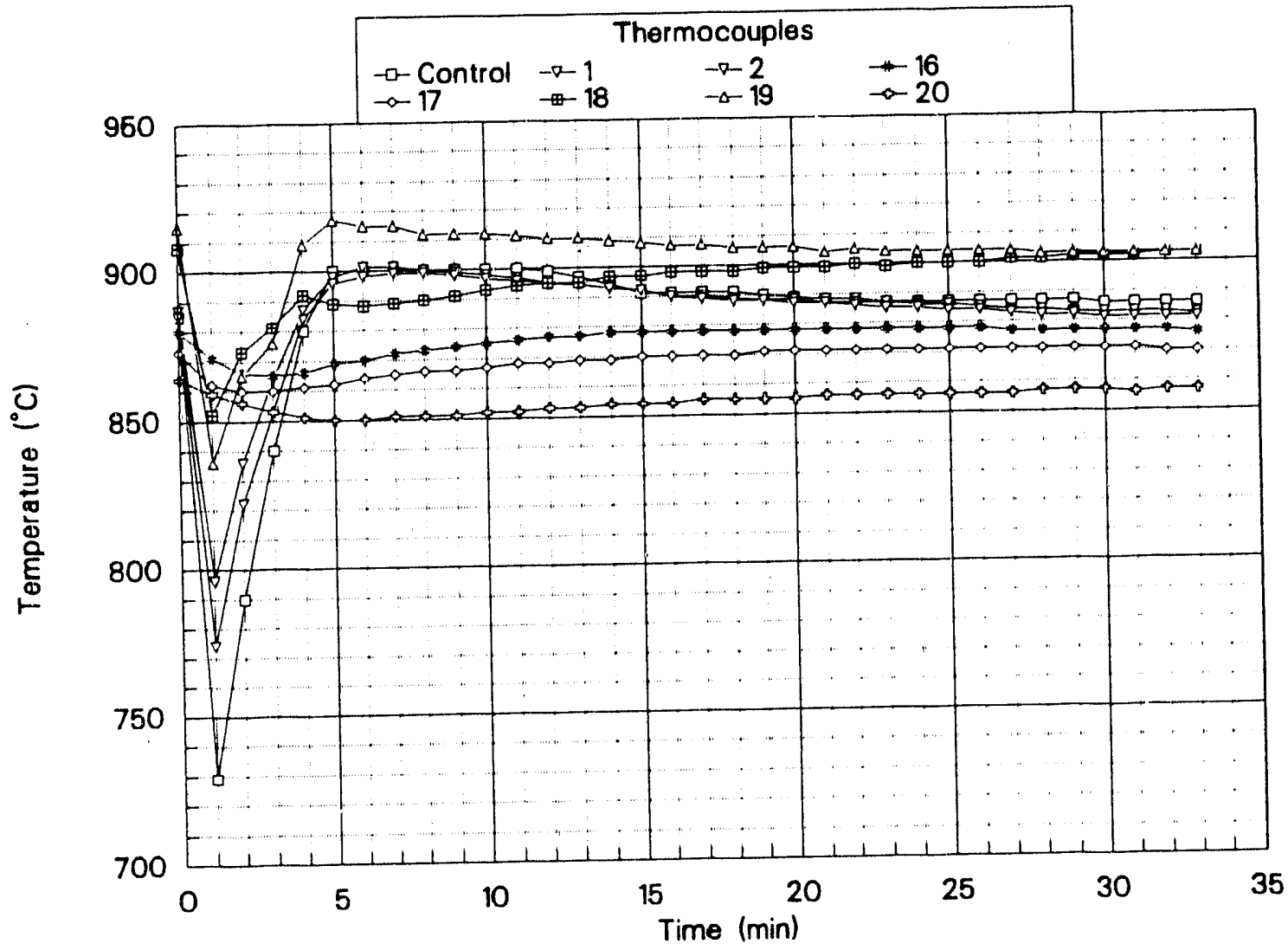

Fig. A.2 Temperature vs time for all monitored furnace locations during experiment 2 , mock sypothetical thermal accident testing of DT-22 container with a furnace set point of $885^{\circ} \mathrm{C}$. 


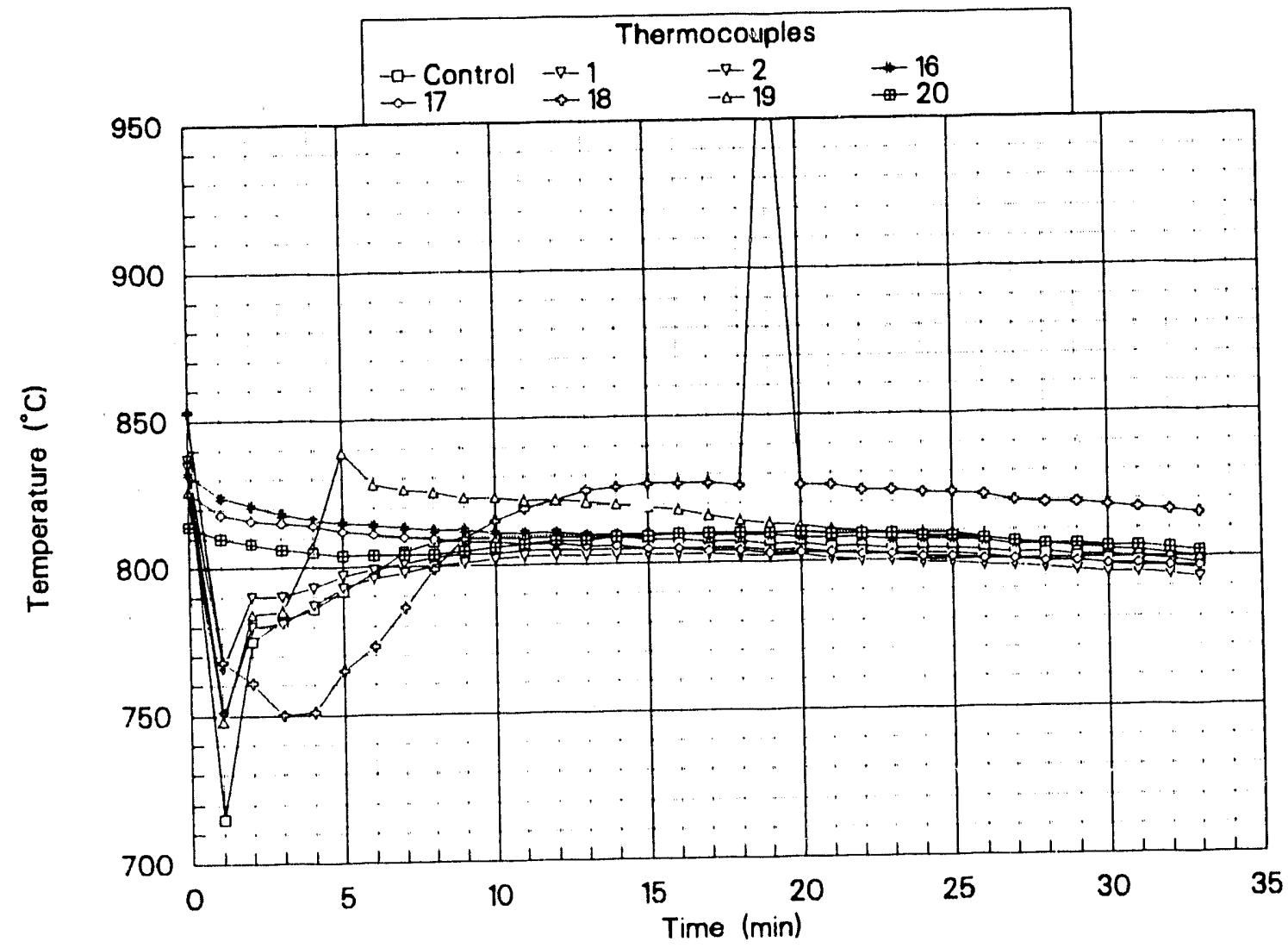

Fig. A.3. Temperature vs time for all monitored furnace locations during experiment 3, mock hypothetical thermal accident testing of DT-22 container in inactive furnace, with a preheat furnace set point of $835^{\circ} \mathrm{C}$. 
Appendix B

DETERMINATION OF NONFUNCTIONING THERMOCOUPLES 


\section{Appendix B}

\section{DETERMINATION OF NONFUNCTIONING THERMOCOUPLES}

A thermocouple located on the furnace wall should be considered to be nonfunctioning if its readings are $50^{\circ} \mathrm{C}$ below the readings of all other monitored furnace thermocouples for more than $3 \mathrm{~min}$.

A thermocouple on the steel plate should be judged to be nonfunctioning if its temperature readings differ by more than $30^{\circ} \mathrm{C}$ from those of all other monitored thermocouples on the plate. 
(a)

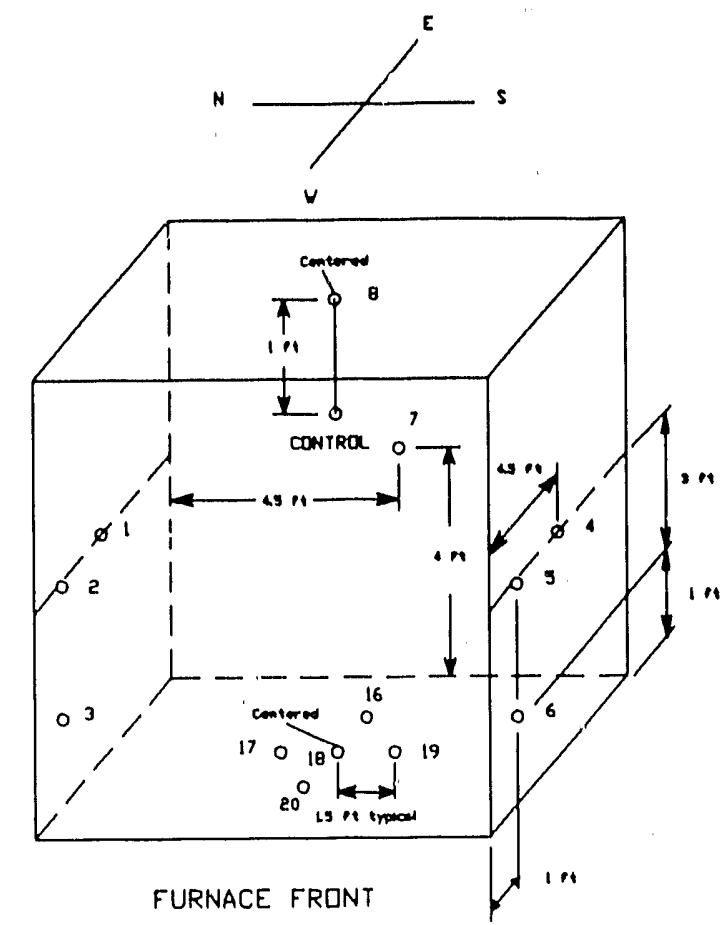

Note, All dimensions are approximate.

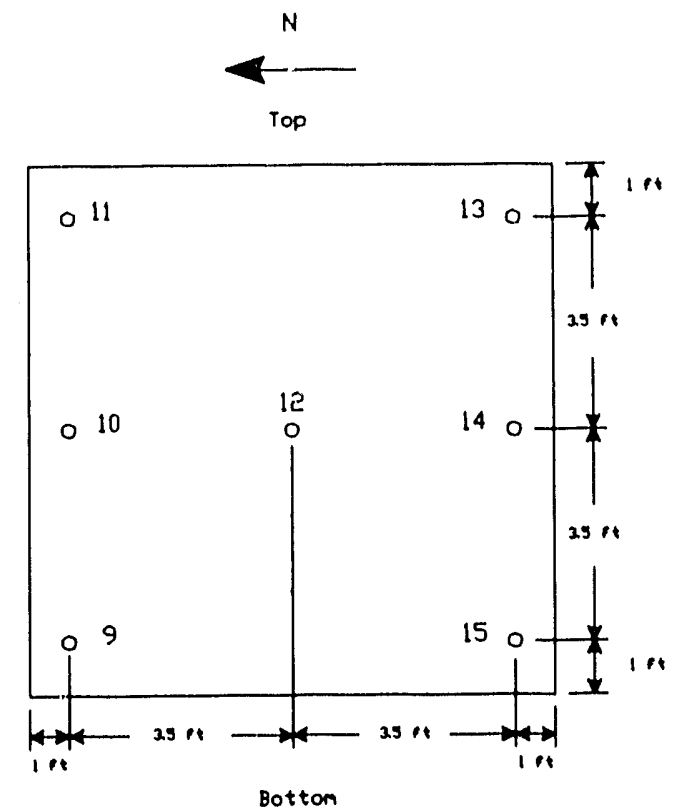

(b)

FURNACE DOQR

Note : All dimensions are approximate.

Thermocouple locations on ( $a$ ) furnace interior and $(b)$ furnace door. 


\section{INTERNAL DISTRIBUTION}

$\begin{array}{llll}\text { 1. } & \text { J. C. Anderson } & 31 . & \text { R. D. Poor } \\ \text { 2. } & \text { H. C. Beeson } & 32 . & \text { J. C. Salyers } \\ \text { 3. } & \text { J. P. Belk } & 33 . & \text { W. C. Stoddart } \\ \text { 4. } & \text { R. W. Bieniek } & 34 . & \text { E. Stumpfl } \\ \text { 5. } & \text { B. B. Bowden } & 35 . & \text { A. J. Szady, Jr. } \\ 6 . & \text { J. R. Dixon } & 36 . & \text { P. A. Tabor } \\ \text { 7. } & \text { D. A. Dyslin } & 37 . & \text { D. A. Tollefson } \\ \text { 8. } & \text { B. F. Elam } & 38 . & \text { M. S. Walker } \\ 9-13 . & \text { M. R. Feldman } & 39 . & \text { J. C. Walls } \\ \text { 14. } & \text { C. P. Frew } & 40 . & \text { D. E. Welch } \\ \text { 15. } & \text { R. W. Glass } & 41 . & \text { W. R. Williams } \\ \text { 16. } & \text { R. F. Holdaway } & 42-43 . & \text { Central Research Library } \\ \text { 17. } & \text { K. G. Kahl } & 44 . & \text { Y-12 Technical Reference Section } \\ \text { 18. } & \text { C. D. Liles } & 45 . & \text { Y-12 Plant Records } \\ \text { 19-28. S. D. Moses } & 46 . & \text { Laboratory Records } \\ 29 . & \text { W. O. Nobles } & 47 . & \text { Laboratory Records - Record Copy } \\ 30 . & \text { T. W. Pickel } & 48 . & \text { ORNL Patent Section }\end{array}$

\section{EXTERNAL DISTRIBUTION}

49. Assistant manager for Energy Research and Development, DOE-OR, P.O.

50. James F. Leonard/EM-321, U. S. Dept. of Energy, RM G-134/GTN, Washington,

51. Roger W. Carlson, Lawrence Livermore National Laboratory, P. O. Box 808, Mail Code L-197, Livermore, CA 94551

52. Larry E. Fischer, Lawrence Livermore National Laboratory, P. O. Box 808, Mail Code L-197, Livermore, CA 94551

53. James H. VanSant, Lawrence Livermore National Laboratory, P. O. Box 808, Mail Code L-197, Livermore, CA 94551

54-65. Office of Science and Technical Information, P. O. Box 62, Oak Ridge, TN 37831 

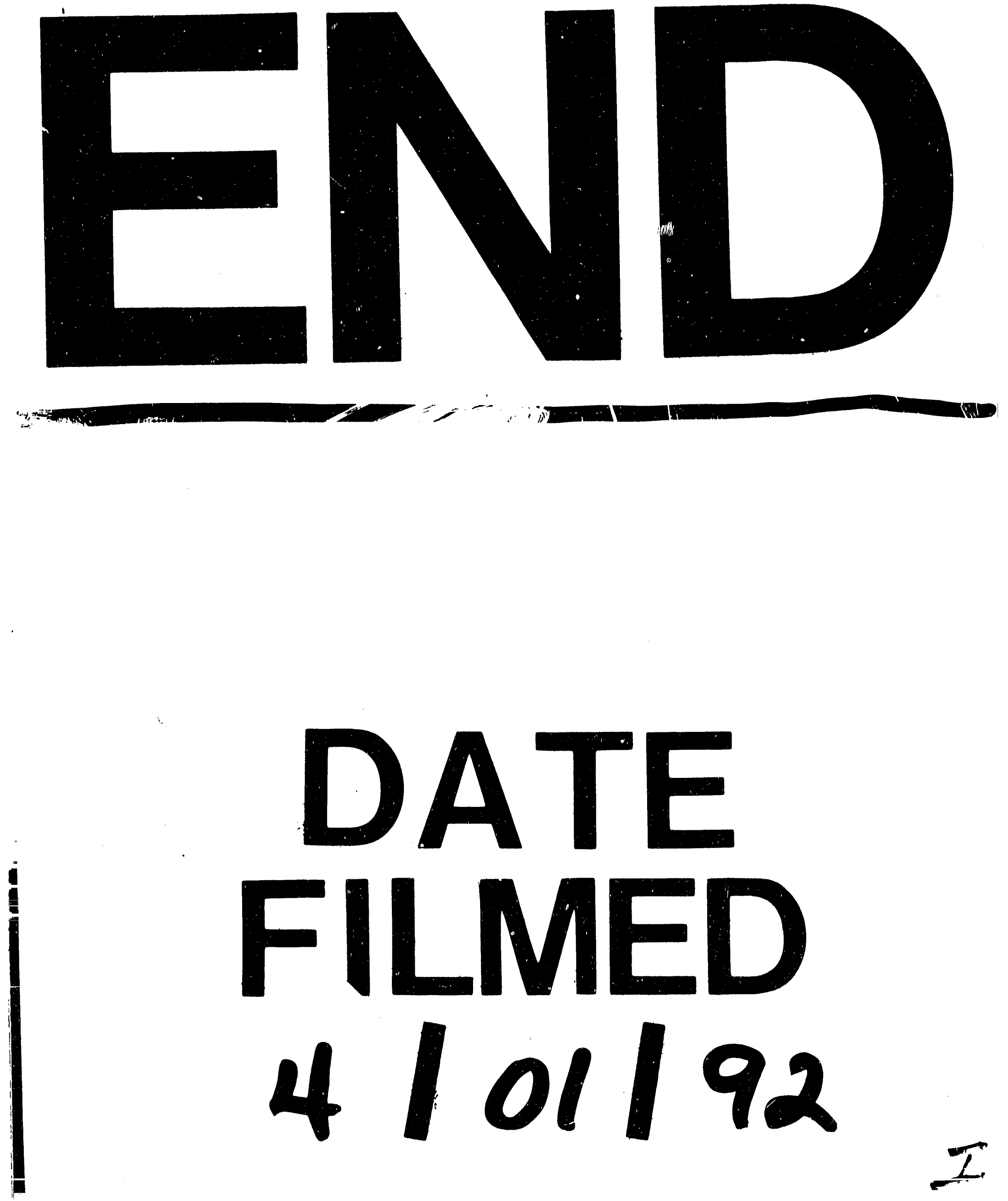
